\title{
Water Quality and Quantity Impacts of Hydraulic Fracturing
}

\author{
Yusuke Kuwayama • Sheila Olmstead • Alan Krupnick
}

Published online: 20 January 2015

(C) Springer International Publishing AG 2015

\begin{abstract}
The academic literature has lagged both industry and public opinion in measuring and characterizing potential water quantity and quality concerns related to hydraulic fracturing (fracking). However, the science behind fracking's water impacts experienced its own boom during the 2010s. In this paper, we address this critical emerging environmental and energy issue, providing an overview of the current state of knowledge, with a particular focus on academic journal articles that have been published in the past five years. These studies have generally found that the water quantity impacts of shale gas and tight oil development are, on average, not significantly worse than for their conventional counterparts, though the specific location and timing of withdrawals for energy development matter. On the other hand, recent findings also suggest that the water quality concerns associated with fracking may be more serious than water quantity concerns.
\end{abstract}

Keywords Shale gas · Unconventional gas · Tight oil · Unconventional oil · Hydraulic fracturing · Surface water . Groundwater $\cdot$ Water quality $\cdot$ Water scarcity

This article is part of the Topical Collection on Energy-Water Nexus

Y. Kuwayama $(\bowtie) \cdot$ A. Krupnick
Resources for the Future, 1616 P Street NW, Washington, DC 20036,
USA
e-mail: kuwayama@rff.org
A. Krupnick
e-mail: krupnick@rff.org
S. Olmstead
LBJ School of Public Affairs, University of Texas at Austin,
P.O. Box Y, E2700, Austin, TX 78713, USA
e-mail: sheila.olmstead@austin.utexas.edu

\section{Introduction}

The production of crude oil and natural gas from unconventional reservoirs has expanded dramatically in recent years, particularly in the United States. U.S. production of natural gas from deep shale formations in particular is projected to continue accelerating through 2040, supplying both the U.S. and foreign markets; U.S. domestic oil production from shale is expected to grow through 2020 and then level off [1].

Exploitation of these resources has been facilitated by advances in several technologies, including hydraulic fracturing, directional drilling, and seismic imaging. The first of these technologies, hydraulic fracturing (fracking), has raised concerns over potential impacts on water resources, as fracked wells are thought to require more water per unit of energy produced than conventional wells, and the chemicals added to the water and pumped underground with high pressure can be damaging to the environment. While public concerns over groundwater and surface water pollution have grown over time, the academic literature has lagged in measuring and characterizing potential water quantity and quality concerns related to fracking.

In the past four years, however, the science of fracking's water impacts has experienced its own boom. This paper addresses this critical emerging environmental and energy issue, providing an overview of the current state of knowledge, most of which thus far has come from study sites in the U.S., where the energy industry and associated manufacturing sectors have been transformed by fracking and the resulting abundance of accessible domestic oil and gas. We focus on the impacts from production of unconventional oil and gas and do not discuss the impacts of their consumption (e.g., in electricity generation or transportation) on water resources, because these impacts would be similar whether energy production were from conventional or unconventional sources. 


\section{Description of Shale gas, Tight oil, and Hydraulic Fracturing}

Shale gas is methane and related gases that occur in fractures and pore spaces between individual mineral grains of lowpermeability shale formations, or that can be adsorbed onto minerals or organic matter within shale rock. Tight oil, sometimes referred to as "shale oil" (not to be confused with oil shale), is similarly found in shale, but can also be produced from other sedimentary rock such as siltstone and sandstone. The presence of these fossil fuel resources within lowpermeability formations requires horizontal drilling and hydraulic fracturing to make their exploitation economically feasible. Though both technologies have a relatively long history-fracking was used commercially in the oil and gas industry as early as 1950, and horizontal wells were common by the late 1970s [2] —innovations in these technologies have driven the recent boom.

Wells for shale gas and tight oil are first drilled vertically, and then turned horizontally to follow the oil- or gas-bearing formation, significantly increasing the surface area of the wellbore exposed to the formation. Multiple lateral wells are typically drilled from a given well pad. Hydraulic fracturing involves injecting water, sand, and chemical additives (such as scale inhibitors, friction reducers, and biocides) into the wellbore at very high pressure so as to create small fractures in the formation and prop open pathways for hydrocarbons to flow out of the well once the pressure is removed.

Shale gas production in the United States grew from about 1 trillion cubic feet (tcf) in 2006 to about 9.7 tcf in 2012, and is expected to grow to about 19.8 tcf in 2040 [1]. U.S. tight oil production was 2.3 million barrels per day in 2012 and is projected to increase to 4.8 million barrels per day by 2021 [1]. The most successful U.S. tight oil plays have been the Bakken in North Dakota and Montana and the Eagle Ford in Texas (see Fig. 1). The U.S. is the dominant producer of tight oil, though by 2020 , up to $10 \%$ of global production is projected to come from other countries [3]. The highest-producing U.S. shale gas plays in 2014 are the Marcellus (accounting for almost $40 \%$ of U.S. shale gas production), Haynesville, and Eagle Ford [4]. The United States and Canada are the world's only major producers of commercially viable shale gas, though ongoing experimentation may eventually lead to significant production in China, Argentina, and elsewhere [5].

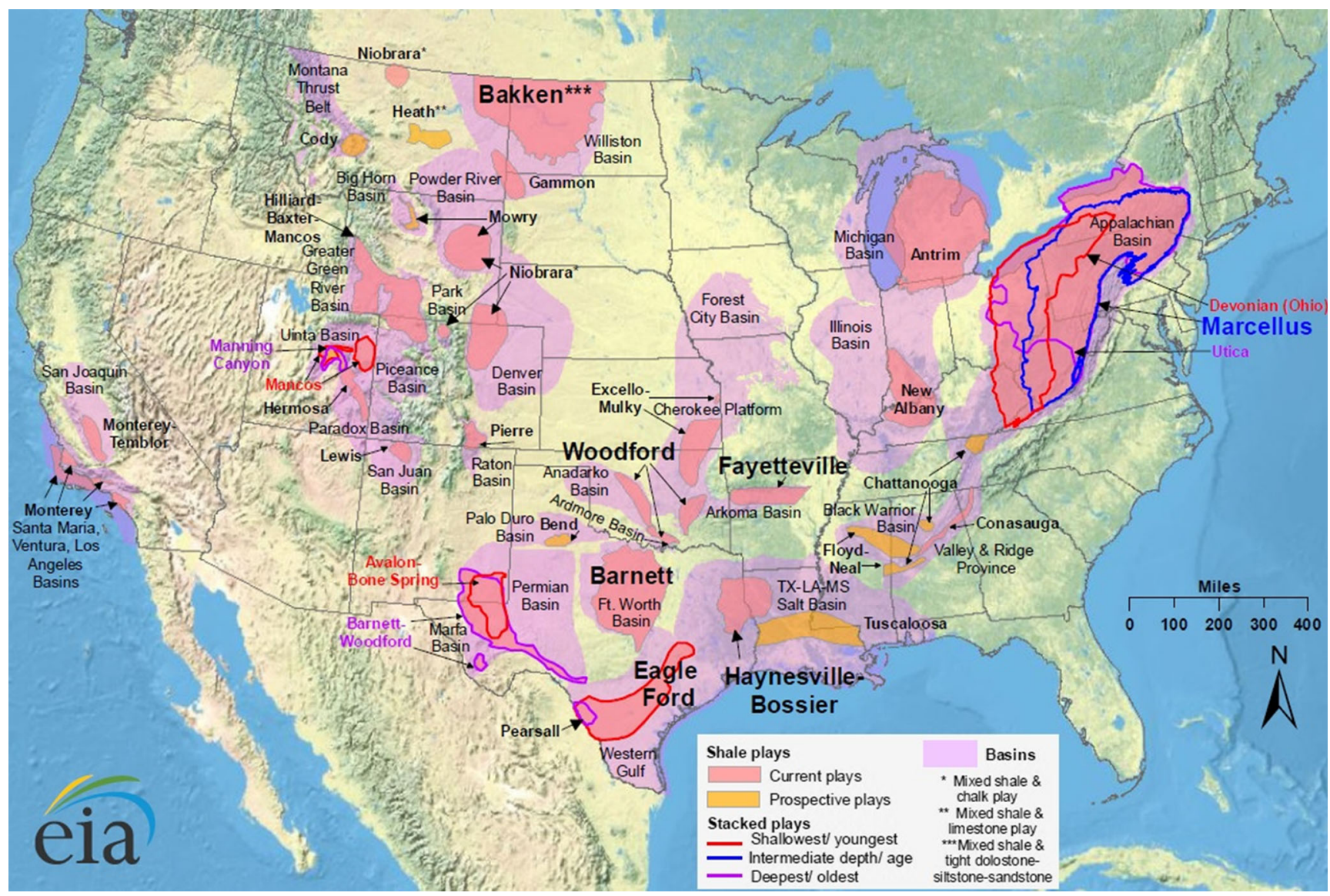

Fig. 1 Map of shale gas and tight oil plays in the Lower 48 States (Source: U.S. Energy Information Administration, http://www.eia.gov/oil_gas/rpd/ shale_gas.pdf) 
The quantity of water used in hydraulic fracturing depends on a number of factors, including the geology of the formation, the amount of recoverable oil and/or gas, and the number of fracture "stages." Wells in the Marcellus Shale in the northeastern United States require 2 to 4 million gallons each [6]. In the Barnett Shale in Texas and Oklahoma, operators use about 5 million gallons of water per well [7]. In 2013, median consumptive use for shale gas wells in northeastern Colorado's Denver-Julesburg Basin was about 2.9 million gallons [8].

While a portion of the injected fracturing fluids stays in the formation, approximately 10 to $40 \%$ may return to the surface as flowback [9]; anecdotal evidence suggests that this figure may be as high as $80 \%$. Flowback is accompanied or followed by water that had been present in the formation ("produced water"), which may be millions of years old and can contain salts, volatile organic compounds, naturally occurring radioactive material, and heavy metals such as arsenic and mercury [10]. Some flowback and (to a smaller extent) produced water can be recycled, but the eventual waste stream is injected into deep underground wells designed to store waste indefinitely, treated and discharged as wastewater, or shipped as solid waste to landfills.

\section{Impacts of Hydraulic Fracturing on Water Quantity and Scarcity}

In describing the impacts of fracking on water quantity, we distinguish, where possible, between water withdrawal and water consumption [11]. The difference between withdrawal and consumptive use in the context of unconventional oil and gas wells varies - perhaps primarily with the wastewater disposal mechanism. Where deep underground injection of flowback and produced water dominates, a high fraction of water withdrawals for fracking represents consumptive use (e.g., $92 \%$ in the Barnett Shale in 2011) [7].

For most shale gas and tight oil resources, fracking itself is likely to be the main consumptive water use in production. When considered in a life-cycle framework, the process of hydraulic fracturing comprises about $85 \%$ of the direct and indirect water consumption associated with an average well in Pennsylvania's Marcellus Shale [12]. Yet, in the Bakken Shale, "maintenance water" pumped into a producing well to flush salts and maintain wellbore integrity may compete with fracking as the top freshwater use over the life of a well [13].

Although fracking and associated activities are water-intensive, in the context of high water use for agricultural irrigation, municipal use, and other purposes, the quantity of water used for producing shale gas in the United States has been small. In 2012, water used for shale gas development in semi-arid western North Dakota represented about $4 \%$ of statewide consumptive use [14]. For other shale plays, recent papers have addressed water withdrawals rather than consumptive use. Freshwater in the humid Marcellus Shale is generally plentiful, and withdrawals for shale gas development represent a very small fraction of total withdrawals [15]. Even in the more arid climates and high extraction states of Texas and Oklahoma, withdrawals amount to less than $1 \%$ of statewide water withdrawals $[16,17]$.

Given these small contributions to overall water withdrawals within a state, regional impacts of shale gas development on water scarcity have been limited. However, the risks associated with water withdrawals can be much larger in a particular place and at a particular time. For example, in Texas' sparsely populated Eagle Ford shale play, water consumption by the shale gas industry represents about $5 \%$ of total consumption in area counties (relative to less than $1 \%$ statewide), and is projected to increase to $89 \%$ of total use during peak production [17]. Within a river basin, small "lower order" streams may be relatively more sensitive to changes in water availability than larger river segments. Small rivers, creeks, and streams with drainage areas less than 100 square miles are the source of about $40 \%$ of surface water withdrawals in the Marcellus Shale [15]. Similarly, groundwater extraction is a more significant concern in areas experiencing rapid depletion (such as the Fox Hills aquifer in North Dakota), and impacts on water tables may be particularly pronounced in narrow glacial valleys and aquifers that are far from large rivers [18]. Risks may also vary over time, either due to the intensity of water use during well completion (relative to well pad development, drilling, and production) or to the potentially more significant impacts of withdrawals during low-flow periods [19].

The water intensity of oil and gas production, which we define as the volume of freshwater consumed per unit of energy in the fuel produced, is a useful measure to compare the impacts of different types of fuels on water quantity. Figure 2 illustrates that, on average, shale gas and tight oil are more water-intensive than conventional gas but less-water intensive than conventional oil. Specifically, the minimum water intensity estimate in the literature for shale gas is less than 1 gal/MMBtu (gallons per million British thermal units of energy), and the maximum estimate is $28 \mathrm{gal} / \mathrm{MMBtu}$, with an average across estimates of $5 \mathrm{gal} / \mathrm{MMBtu}$ [20-32]. The minimum water intensity estimate in the literature for tight oil is $1.6 \mathrm{gal} / \mathrm{MMBtu}$, while the maximum estimate is $21.7 \mathrm{gal} / \mathrm{MMBtu}$, with an average across estimates of $8.2 \mathrm{gal} / \mathrm{MMBtu}[20,21,30]$.

Therefore, to the extent that shale gas supplants conventional gas development, total water use would increase. However, if projected growth in shale gas and oil production offsets conventional oil production, it is possible that total water use in the future may be less than what would have occurred in the absence of shale development. The latter finding is 


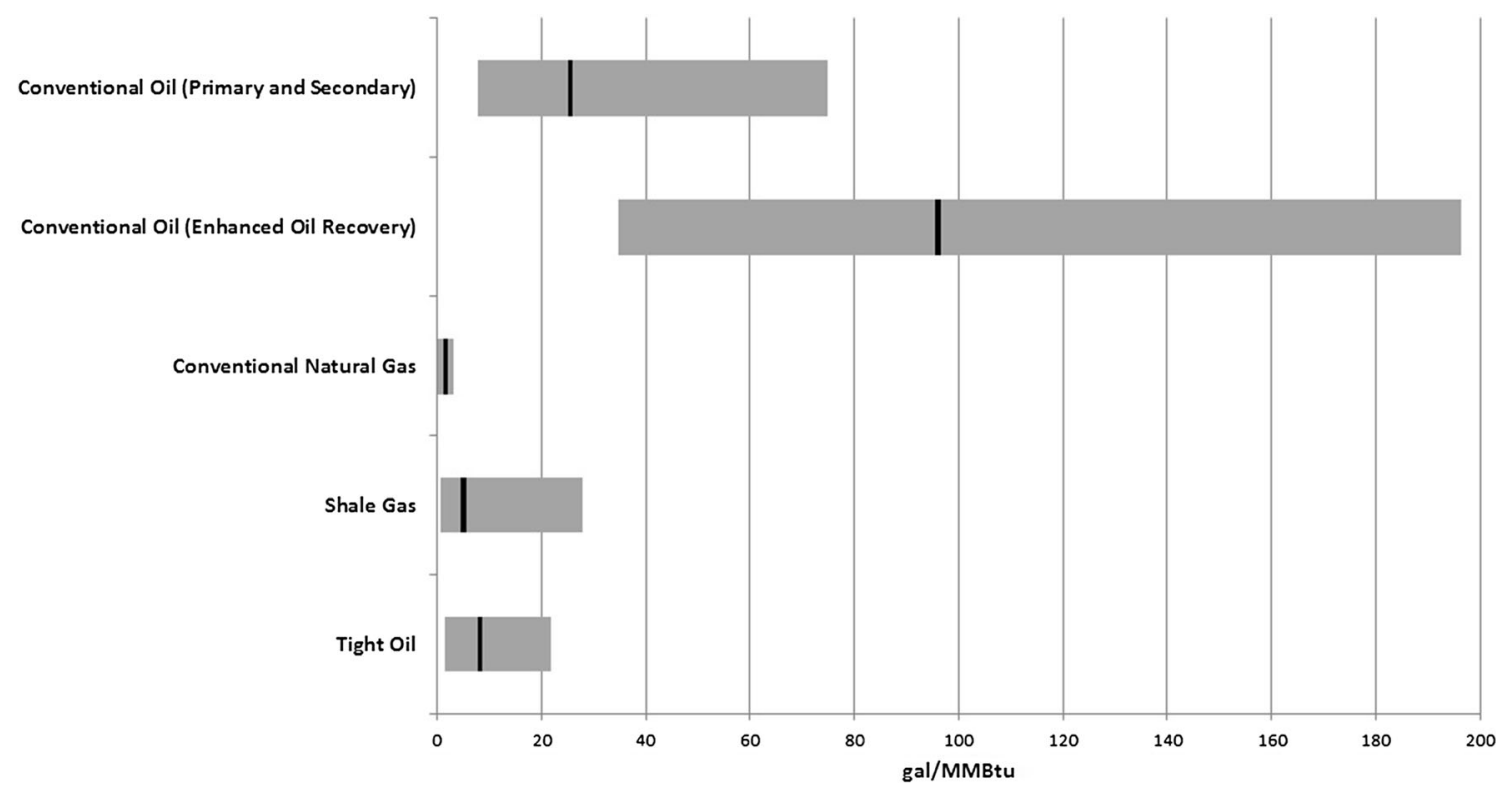

Fig. 2 Ranges and averages of water intensity estimates available in the literature (estimates for conventional oil and gas obtained from [22, 27, 28, 60-65])

particularly likely if conventional oil is produced using an enhanced oil recovery (EOR) process that involves water.

\section{Impacts of Hydraulic Fracturing on Water Quality}

Several actual and potential water quality impacts of hydraulic fracturing have been identified in the literature, though many have less to do with the process of fracking itself than with site preparation, waste disposal, and other processes. Nonetheless, most of these impacts would be of little or no concern without the ongoing vast increase in energy development made possible by fracking. We divide these impacts into two groups, those primarily affecting surface water and those primarily affecting groundwater.

\section{Surface Water Quality Impacts}

Avenues through which shale gas and tight oil development may affect water quality in rivers and streams include accidental release of fracking fluid, flowback, or produced water, as well as liquid waste storage, treatment, and disposal. The clearing of land for new well pads and other infrastructure may also generate impacts. We consider each of these separately in the paragraphs that follow.

The potential for the accidental release to surface water of fracking fluids, flowback, and produced water (or oil and gas condensates themselves) has been a significant focus of public concern. Individual incidents involving spills of fluids that are either inputs to or outputs from shale gas and tight oil wells in the Bakken, the Marcellus, and other active shale plays are easy to identify with a quick search of local newspapers (see, for example, Warco, Kathie. 2010. "Fracking truck runs off road; contents spill." Washington PA Observer Reporter. 21 October; and Nowatzki, Mike. 2013. "Saltwater spills can cause lasting damage." Prairie Business, 18 November.)

Thus far, however, there is little peer-reviewed evidence that accidental releases associated with shale gas and tight oil development have significantly affected surface water. A study of surface water quality impacts from shale gas development in Pennsylvania found no systematic evidence of accidental releases from gas wells in analyzing water quality downstream of these wells, even when focusing on the period of well completion [33]. However, in at least one case, a documented spill has been analyzed in the peer-reviewed literature; a 2007 accidental release of fracking fluids to a creek in Kentucky had toxic impacts on fish, including two federally protected species, lasting several months [34]. More research on this topic may support the development (and application) of appropriate risk management strategies and public policies regarding such spills, and may also address public concerns about actual and potential spills.

Possibly the most significant measured impacts of shale gas and tight oil development on surface water quality thus far have to do with the release of partially treated wastewater to rivers and streams. Like freshwater inputs, liquid waste outputs (mostly flowback and produced water, but also drilling muds and fluids) from drilling and fracking are highly variable. In the Marcellus Shale, 9 to $53 \%$ of fracking fluid inputs may return as flowback, along with formation brine [35]. The common contaminants in this waste stream create a waste treatment challenge. Average total dissolved solids (TDS) concentrations in the Marcellus Shale exceed 100,000 milligrams per liter 
$(\mathrm{mg} / \mathrm{L})[36,37]$; the typical ocean water concentration is $35,000 \mathrm{mg} / \mathrm{L}$, and fresh water is $100-500 \mathrm{mg} / \mathrm{L} \mathrm{[38].}$

Produced water TDS concentrations vary significantly within U.S. shale plays, with the Marcellus among the saltiest and the Fayetteville (at 25,000 mg/L) somewhat below concentrations observed in seawater [10]. Treatment of waste high in TDS is expensive and energy-intensive, as dissolved solids are not easily removed by chemical or biological processes. One potential solution is to power on-site wastewater treatment processes by recovering natural gas that would otherwise be flared. A recent study finds that the volume of gas that was flared in Texas in 2012 would be sufficient to cover the thermal energy requirements to yield treated wastewater to meet the needs of fracking 9,400 to 28,000 wells [39].

Most flowback in the Marcellus is now recycled to frack additional wells, with the remaining stream of liquid waste from both flowback and produced water either trucked to industrial wastewater treatment facilities or transported to deep injection wells [12]. Operators in western shale plays recycle much less than those in the east, and little, if any, liquid waste moves through wastewater treatment facilities in these regions-deep injection is an almost universally available, cost-effective, and low-risk disposal option in the absence of seismic activity $[40,41]$. In many shale plays, the stream of new wastewater associated with fracking, whether destined for wastewater treatment facilities or deep injection, represents a very significant increase over pre-fracking flows. For example, in the Marcellus Shale, wastewater flows from shale gas development represent a $570 \%$ increase over baseline oil and gas wastewater flows in 2004 [42]. In the Bakken, state data show that for every barrel of oil produced, a barrel of wastewater must be disposed (MacPherson, James. 2014. "Pipeline leaks brine in Lake Sakakawea tributary." Bismarck Tribune, 10 October).

Shipments of flowback and produced water from Marcellus Shale gas wells to municipal and industrial wastewater treatment plants have raised regulatory and public health questions. In 2011, the Commonwealth of Pennsylvania banned shipments to municipal sewage treatment plants, though industrial chemical waste treatment (CWT) facilities have continued to play a significant role in shale gas waste treatment and disposal [43]. Chemical analysis of effluent discharged from municipal sewage treatment plants in Pennsylvania before and after the Commonwealth's shipment ban found that concentrations of barium, strontium, bromides, chlorides, TDS, and benzene were reduced in the majority of samples after the ban, which suggests that these treatment plants may not have been providing sufficient treatment of shale gas waste [44].

Downstream surface water quality impacts from incomplete wastewater treatment by CWTs have been demonstrated for chloride [33] and bromide [45]. Increases in these dissolved solids may damage economically important species such as brook trout [46], and have contributed to observed increases in carcinogenic disinfection by-products (which increase in the presence of bromide) in finished drinking water in the region's cities [45]. Radionuclides from treated flowback and produced water are also accumulating in stream sediments after partial removal by CWTs, raising questions about longrun impacts on human and ecosystem health [43, 47].

While water pollution from the release of partially treated flowback and produced water into rivers and streams is a serious problem, it is regional in nature. Most U.S. regions with significant shale gas resources also have plentiful deepinjection well capacity for liquid waste disposal. Thus the global impacts of fracking on water quality may be critically dependent on the availability of appropriate treatment and disposal mechanisms for flowback, produced water, fracking fluids, drilling muds, and other waste.

Finally, the rapid increase in shale gas and tight oil development since the middle of the last decade has resulted in extensive growth of infrastructure. Development of these resources requires land clearing; well pad, pipeline, and road construction; installation of impervious surfaces; and high truck traffic for water, wastewater, and hydrocarbon transport. All of these activities may increase stormwater runoff, erosion, and sedimentation of local rivers and streams. Empirical evidence of increases in total suspended solids (TSS) downstream of shale gas well pads in Pennsylvania is provided in Olmstead et al. [33]. Given the importance of nonpoint sources of impairment in U.S. watersheds, land disturbance associated with future energy development at the scale made possible by hydraulic fracturing may pose a significant threat to aquatic ecosystems [48]. On-site storage of produced water and flowback in pits and tanks also poses major risks to water resources, as identified in a survey of experts [49]. Incident reports kept by regulators in Colorado, New Mexico, and Oklahoma contain records of spills, leaks, and overflows of drilling and fracturing fluid, brine, crude oil, and additives such as hydrochloric acid and potassium chloride.

\section{Groundwater Quality Impacts}

The potential for contamination of groundwater from hydraulic fracturing has received significant attention in the popular media. Much of the public attention focuses on the process of hydraulic fracturing - the idea that fracturing shale formations will either create new conduits through which contaminants may migrate up from the targeted shale plays to overlying groundwater, or encourage their migration through existing conduits. The potential for the movement of brines and fracking fluids from deep shale formations to overlying aquifers through natural or induced fractures in both the short and long run is debated in the scientific literature [10, 50]. Typically, a large vertical separation exists between the shale sections being fractured and the shallow groundwater zones that contain potable water that may be a source of drinking water 
for local communities, These separations, with the exception of the Antrim, New Albany, and Fayetteville Shale plays in the United States, are several thousand feet thick, [29, 51].

Another well-known issue, in both conventional and unconventional drilling, is isolation of the wellbore - through which gas, oil, drilling muds, fracking fluids, and produced water flow-from the aquifer through which it passes. Failures of well integrity (leaky or poorly applied casing and cementing) are thought by experts to be the more pressing concern [49]. Case studies of isolated groundwater contamination incidents suggest links with shale gas activity. For example, in Pavilion, Wyoming, studies by two federal agencies found contamination in groundwater wells from shale gas activities [52, 53]. In Alberta, an energy developer inadvertently fractured a shale gas well above its intended subsurface target, contaminating groundwater in the process [54].

Definitive empirical evidence of systematic groundwater contamination has been slower to emerge than evidence of surface water pollution. A recent study involving 100 private drinking water wells in aquifers overlying the Barnett Shale detected higher levels of arsenic, selenium, strontium, and barium at water wells located within 3 kilometers of active natural gas wells relative to water wells located farther away [55]. However, this study stopped short of drawing definitive conclusions regarding the origin of these elevated constituent levels. Regions with plentiful methane and brine in the subsurface often have high methane and salt levels in groundwater, and thus it can be difficult to detect the impact of energy development on groundwater quality.

Some evidence suggests that movement of methane from shale gas wells to groundwater wells in overlying aquifers may have occurred in the Marcellus [56-58] and Barnett shale plays [56], but these studies have been controversial and have been challenged as lacking evidence that the methane came from the fractured area. A related study in the Arkansas Fayetteville Shale did not detect evidence in groundwater of stray gas contamination, or contamination by brine [59]. Results from studies observing methane in water wells near shale gas development are consistent with well casing and cementing failures rather than upward migration from the shale formations through fracking itself (or through natural conduits) [56]. The fact that current research points to faulty casing and cementing (rather than fracking, per se) as the likely cause of observed groundwater contamination suggests the need for additional scientific and policy analysis in this area.

\section{Conclusions}

Current and expected future growth of shale gas and tight oil development using hydraulic fracturing has raised concerns regarding potential impacts on water quantity and quality.
This paper has provided an overview of the current literature on the water resource implications of these activities.

Our overview leads to several key findings. First, we find that, on average, the impacts of shale gas production on water quantity are not significantly worse than those of their conventional counterparts. However, the specific location and timing of water use for fracking matters, and localized negative impacts are possible. Second, there is evidence that tight oil production may be less water-intensive than conventional oil production, especially if secondary recovery or EOR are involved. This would imply that if shale gas and oil production offsets conventional oil production in the future, total water use may be less than what would have occurred in the absence of shale gas oil development.

Third, academic research over the last four years suggests that water quality concerns associated with fracking may be more serious than water quantity concerns. The literature has identified more definitive links between shale gas development and impacts on surface water quality, and emerging research is consistent with groundwater quality impacts. The rapid pace of expansion in the industry suggests that new research aimed at quantifying water quality impacts, characterizing their pathways, and assessing options (for industry and/or policymakers) for their mitigation will have high value.

Acknowledgments We thank Will Isaac and Skyler Roeshot for excellent research assistance. This article is based upon work supported by the S. D. Bechtel, Jr. Foundation.

\section{Compliance with Ethics Guidelines}

Conflict of Interest Yusuke Kuwayama and Sheila Olmstead have received grants from the S. D. Bechtel, Jr. Foundation.

Alan Krupnick declares that he has no conflict of interest.

Human and Animal Rights and Informed Consent This article does not contain any studies with human or animal subjects performed by any of the authors.

\section{References}

1. U.S. Energy Information Administration, Annual Energy Outlook 2014 Early Release, 2014.

2. King G.E., Hydraulic Fracturing 101: what every representative, environmentalist, regulator, reporter, investor, university researcher, neighbor and engineer should know about estimating frac risk and improving frac performance in unconventional oil and gas wells. , in Society of Petroleum Engineers Fracturing Technology Conference 2012, SPE 152596: The Woodlands, Texas. p. 80.

3. Webster J. Going Global: Tight Oil Production, Leaping out of North America and onto the World Stage. in U.S. Energy Information Administration Energy Conference 2014: Washington, D.C.

4. U.S. Energy Information Administration, Drilling Productivity Report for Key Tight Oil and Shale Gas Regions, 2014, U.S. Energy Information Administration: Washington. 
5. U.S. Energy Information Administration, Technically Recoverable Shale Oil and Shale Gas Resources: An Assessment of 137 Shale Formations in 41 Countries outside the United States, 2013: Washington, D.C.

6. Veil J, Water Management Technologies Used by Marcellus Shale Gas Producers, Final Report, A.N.L. U.S. Department of Energy, Editor 2010: Argonne, IL.

7. Nicot J-P et al. Source and fate of hydraulic fracturing water in the Barnett shale: a historical perspective. Environ Sci Technol. 2014;48(4):2464-71.

8. Goodwin $\mathrm{S}$ et al. Water intensity assessment of shale gas resources in the Wattenberg field in northeastern Colorado. Environ Sci Technol. 2014;48(10):5991-5.

9. Gregory KB, Vidic RD, Dzombak DA. Water management challenges associated with the production of shale gas by hydraulic fracturing. Elements. 2011;7(3):181-6.

10. Vengosh A et al. A critical review of the risks to water resources from unconventional shale gas development and hydraulic fracturing in the United States. Environ Sci Technol. 2014;48(15):8334-48.

11. Kenny J, et al., Estimated Use of Water in the United States in 2005 , U.S.G. Survey, Editor 2009: Reston, VA.

12. Jiang M, Hendrickson CT, VanBriesen JM. Life cycle water consumption and wastewater generation impacts of a Marcellus shale gas well. Environ Sci Technol. 2014;48(3):1911-20.

13. Gordon, D. and K. Garner, Underestimating Oil and Water Challenges in the Northern Great Plains, 2014, Carnegie Endowment for International Peace.

14. North Dakota State Water Commission, Facts about North Dakota Fracking and Water Use, N.D.S.W. Commission, Editor 2014: Bismarck.

15. Mitchell A, Small M, Casman EA. Surface water withdrawals for Marcellus shale gas development: performance of alternative regulatory approaches in the Upper Ohio River Basin. Environ Sci Technol. 2013;47(22):12669-78.

16. Murray KE. State-scale perspective on water use and production associated with oil and gas operations, Oklahoma. US Environ Sci Technol. 2013;47(9):4918-25.

17. Nicot J-P, Scanlon BR. Water use for shale gas production in Texas. US Environ Sci Technol. 2012;46(6):3580-6.

18. Best LC, Lowry CC. Quantifying the potential effects of highvolume water extractions on water resources during natural gas development: Marcellus shale. NY Journal of Hydrology: Regional Studies. 2014;1:1-16.

19. Entrekin $\mathrm{S}$ et al. Rapid expansion of natural gas development poses a threat to surface waters. Front Ecol Environ. 2011;9:503-11.

20. Anderson A., et al., Water/Energy Nexus, 2011, National Petroleum Council

21. Chesapeake Energy Corporation, Water Use in Deep Shale Gas Exploration, 2012.

22. Clark CE, Horner RM, Harto CB. Life cycle consumption for shale gas and conventional natural gas. Environ Sci Technol. 2013;47(20): 11829-36.

23. Goodwin $\mathrm{S}$ et al. Life cycle analysis of water use and intensity of oil and gas recovery in Wattenberg field. Colo Oil Gas J. 2012;110(5): 48-59.

24. Grubert EA, Beach FC, Webber ME. Can switching fuels save water? A life cycle quantification of freshwater consumption for Texas coaland natural gas-fired electricity. Environ Res Lett. 2012;7(045801): 11

25. International Energy Agency, Golden Rules for a Golden Age of Gas: World Energy Outlook Special Report on Unconventional Gas, 2012: Paris, France.

26. Laurenzi IJ, Jersey GR. Life cycle greenhouse gas emissions and freshwater consumption of Marcellus shale gas. Environ Sci Technol. 2013;47(9):4896-903.
27. McMahon J, Price S. Water and energy interactions. Annu Rev Environ Resour. 2011;36:163-91.

28. Mielke E, L.D. Anadon and V. Narayanamurti, Water Consumption of Energy Resource Extraction, Processing, and Conversion 2010, Harvard Kennedy School Belfer Center for Science and International Affairs.

29. Moniz E., H. Jacoby, and A. Meggs, The Future of Natural Gas: An Interdisciplinary MIT study 2011, Massachusetts Institute of Technology.

30. Scanlon B.R. R.C. Reedy, and J.-P. Nicot, Comparison of Water Use for Hydraulic Fracturing for Unconventional Oil and Gas versus Conventional Oil. Environ. Sci. Technol., 2014. Article ASAP.

31. World Economic Forum and Cambridge Energy Research Associates, Energy Vision Update 2009: Thirsty Energy: Water and Energy in the 21st Century, 2008: Geneva, Switzerland.

32. Mantell M.E., Deep Shale Natural Gas and Water Use, Part Two: Abundant, Affordable, and Still Water Efficient, 2010, Chesapeake Energy Corporation: Oklahoma City, OK.

33. Olmstead SM et al. Shale Gas development impacts on surface water quality in Pennsylvania. Proc Natl Acad Sci U S A. 2012;110(13): 4962-7.

34. Papoulias DM, Velasco AL. Histopathological analysis of fish from Acorn Fork Creek, Kentucky exposed to hydraulic fracturing fluid releases. Southeast Nat. 2013;12(4):92-111.

35. Vidic, R.D., et al., Impact of Shale Gas Development on Regional Water Quality. Science, 2013. 340(6134).

36. Barbot E et al. Spatial and temporal correlation of water quality parameters of produced waters from Devonian-age shale following hydraulic fracturing. Environ Sci Technol. 2013;47(6):2562-9.

37. Haluszczak LO, Rose AW, Kump LR. Geochemical evaluation of flowback brine from Marcellus Gas wells in Pennsylvania. USA Appl Geochem. 2013;28:55-61.

38. Pennsylvania State University and College of Agricultural Sciences, Shaping Proposed Changes to Pennsylvania's Total Dissolved Solids Standard: A Guide to the Proposal and the Commenting Process, 2010, 2010: University Park, PA.

39. Glazer YR et al. Potential for using energy from flared gas for on-site hydraulic fracturing wastewater treatment in Texas. Environ Sci Techno Lett. 2014;1:300-4.

40. Horton S. Disposal of hydrofracking waste fluid by injection into subsurface aquifers triggers earthquake swarm in central Arkansas with potential for damaging earthquake. Seismol Res Lett. 2012;83(2):250-60.

41. Frolich C. Two-year survey comparing earthquake activity and injection-well locations in the Barnett shale. Texas Proc Natl Acad Sci USA. 2012;109(35):13934-8.

42. Lutz BD, Lewis AN, Doyle MW. Generation, transport, and disposal of wastewater associated with Marcellus shale gas development. Water Resour Res. 2013;49(2):647-56.

43. Zhang $\mathrm{T}$ et al. Co-precipitation of radium with barium and stronium sulfate and its impact on the fate of radium during treatment of produced water from unconventional gas extraction. Environ Sci Technol. 2014;48(8):4596-603.

44. Ferrar KJ et al. Assessment of effluent contaminants from three facilities discharching Marcellus shale wastewater to surface waters in Pennsylvania. Environ Sci Technol. 2013;47(7):3472-81.

45. Wilson JM, Briesen JMV. Source water changes and energy extraction activities in the Monongahela River, 2009-2012. Environ Sci Technol. 2013;47(21):12575-82.

46. Weltman-Fahs M, Taylor JM. Hydraulic fracturing and brook trout habitat in the Marcellus shale region: potential impacts and research needs. Fisheries. 2014;38(1):4-15.

47. Warner NR et al. Impacts of shale gas wastewater disposal on water quality in western Pennsylvania. Environ. Sci Technol. 2013;47(20): $11849-57$ 
48. Jr., G.A.B..., et al., Hydrualic "fracking": Are surface water impacts an ecological concern? Environ. Toxicol. Chem., 2014. 33(8): p. 16791689.

49. Krupnick, A., H. Gordon, and S. Olmstead, Pathways to Dialogue: What the Experts Say about the Environmental Risks of Shale Gas Development. RFF Report Resources for the Future: Washington, DC.

50. Engelder T, Cathles LM, Bryndzia LT. The fate of residual treatment water in gas shale. J Unconv Oil Gas Resour. 2014;7:33-48.

51. Ground Water Protection Council and ALL Consulting, Modern Shale Gas Development in the United States: A Primer, 2009: U.S. Department of Energy.

52. U.S. Environmental Protection Agency, Investigation of Ground Water Contamination Near Pavillion, Wyoming, 2011: Ada, OK.

53. Wright, P., et al., Groundwater-quality and Quality-control Data for Two Monitoring Wells near Pavillion, Wyoming, April and May 2012, 2012, U.S. Geological Survey: Reston, VA.

54. Energy Resources Conservation Board, Alberta's Energy Reserves 2010 and Supply/Demand Outlook 2011-2020, 2010, Energy Resources Conservation Board: Calgary, Alberta.

55. Fontenot BE et al. An evaluation of water quality in private drinking water wells near natural gas extraction sites in the Barnett shale formation. Environ Sci Technol. 2013;47(17):10032-40.

56. Darrah TH et al. Noble gases identify the mechanisms of fugitive gas contamination in drinking-water wells overlying the Marcellus and Barnett shales. Proc Natl Acad Sci U S A. 2014;111(39):14076-81.
57. Jackson RB et al. Increased stray gas abundance in a subset of drinking water wells near Marcellus shale gas extraction. Proc Natl Acad Sci U S A. 2013;110(28):11250-5.

58. Osborn SG, Vengosh A, Warner NR. Methane contamination of drinking water accompanying gas-well drilling and hydraulic fracturing. Proc Natl Acad Sci U S A. 2011;108(20):8172-6.

59. Warner NR et al. Geochemical and isotopic variations in shallow groundwater in areas of the Fayetteville shale development. North-Central Arkansas Appl Geochem. 2013;35:20720.

60. Glassman D., et al., The Water-Energy Nexus: Adding Water to the Energy Agenda, 2011, World Policy Institute and EBG Capital.

61. Gleick P. Water and energy. Annu Rev Energy Environ. 1994;19: 267-99.

62. Grubert E. and S. Kitasei, How Energy Choices Affect Fresh Water Supplies: A Comparison of U.S. Coal and Natural Gas, 2010, World Watch Institute: Washington, DC.

63. Pate R., et al., Overview of Energy-Water Interdependencies and the Emerging Energy Demands on Water Resources, 2007, Sandia National Labroatories: Albuquerque, NM.

64. U.S. Department of Energy, Energy Demands on Water Resources: Report to Congress on the Inderdependency of Energy and Water, December 2006, 2006: Washington, DC.

65. Wu M., et al., Consumptive Water Use in the Production of Ethanol and Petroleum Gasoline, 2009, Argonne National Laboratory: Lemont, IL. 